\title{
Metacarpal Bone
}

National Cancer Institute

\section{Source}

National Cancer Institute. Metacarpal Bone. NCI Thesaurus. Code C12751.

Any of the five bones between the wrist and the fingers that form the skeleton of the palm. 